\title{
The comparison of competitive balance in Football Premier Leagues of England, Germany, Spain, France, Italy and Iran: A case study from 2009-2010 Season
}

\author{
SALAH NAGHSHBANDI ${ }^{1}$, BAHRAM YOUSEFI ${ }^{2}$, ZAHER ETEMAD $^{3}$, MEHDI MORADI $^{1}$ \\ ${ }^{1}$ Dept of Physical Education, Science and Research Branch, Islamic Azad University, Sanandaj, Iran \\ ${ }^{2}$ Department of Physical Education, Razi University, Kermanshah, Iran \\ ${ }^{3}$ Department of Physical Education, Sanandaj Branch, Islamic Azad University, Sanandaj, Iran
}

\begin{abstract}
Naghshbandi S, Yousefi B, Etemad Z, Moradi M. The comparison of competitive balance in football Premier Leagues of England, Germany, Spain, France, Italy and Iran: A case study from 2009-2010 Season. J. Hum. Sport Exerc. Vol. 6, No. 4, pp. 673-681, 2011. Most sports are attractive because they are almost unpredictable. The more the competitiveness of league teams, the harder to predict the games and as a result, that league will be more attractive. Competitive balance refers to the balance in sport capabilities of teams. The aim of this paper was to compare the competitive balance in football premier leagues of Iran, England, Germany, Spain, France and Italy in 2009-2010 season. The data were secondary and collected from the final tables of premier leagues of those countries in 2009-2010 season. The five-club concentration ratio (C5) and $\mathrm{C} 5$ index of competitive balance (C5ICB) were used to analyze the data. The less C5ICB and C5 are, the more competitive balance is, and conversely. The C5ICB results showed that the leagues were ranked (ranging from most balance to least balance) as follows: Iran Pro League (129.60), Germany Bundesliga (135.37), French 1st League (138), Serie A, Italy (140), English Premier League (148) and Primera Liga, Spain (149.60). As a result, Iran premier league enjoyed the most balance and Primera Liga, Spain the least balance. In spite of the sport economics research representing lack of comparability between European leagues and other leagues in world, competitive balance has been decreased clearly in European leagues. Key words: COMPETITIVE BALANCE, FOOTBALL PREMIER LEAGUE, FIVE-CLUB CONCENTRATION RATIO (C5), C5 INDEX OF COMPETITIVE BALANCE (C5ICB).
\end{abstract}

Corresponding author. Department of Physical Education, Science and Research Branch, Islamic Azad University, Sanandaj, Iran

E-mail: salahnaghshbandi@yahoo.com

Submitted for publication April 2011

Accepted for publication October 2011

JOURNAL OF HUMAN SPORT \& EXERCISE ISSN 1988-5202

(C) Faculty of Education. University of Alicante

doi:10.4100/jhse.2011.64.10 


\section{INTRODUCTION}

We cannot image the world without football so that the countries which act as FIFA members $(n=207)$ are more than those as UN members $(n=192)$. In most countries, football federation is the biggest sport federation. Football is most broadcast and the players are paid most. Asia 2002 World Cup and Africa 2010 World Cup show that people are more and more interested in football worldwide (Albert et al., 2008). In recent decades, football has changed into a multi-billion dollar industry and football federation statistics show that there are more than 200 million football players worldwide (Halicioglu, 2006). Football industry has occupied 3\% of world trade (Szymansky, 2001). Most sports are attractive because they are almost unpredictable. So, organizations and government departments attempt to maximize the unpredictability of the games by implementing limitations for teams and players (Koning, 2000). The more the competitiveness of league teams, the harder to predict the games and as a result, that league will be more attractive (Michie et al., 2005). In a completely balanced league, each team enjoys an equal chance to win a game and as a result, to win the league (Michie et al., 2004).

Competitive balance refers to the balance in sport capabilities of teams (Michie et al., 2004). Uncertainty in football results are investigated by various methods, but Szymanski (2003) identifies three kinds of uncertainty: a) match uncertainty which refers to the uncertainty about the result of a special match (between two teams) b) season uncertainty which refers to uncertainty about the matches of a season c) championship uncertainty which refers to the dominance of a limited number of teams over the league in consecutive seasons (Szymansky, 2003). However, any attempt to increase attention and the audience and as a result competitiveness may seem inappropriate from the viewpoint of a special club or fans, especially when they believe that the possibility of winning the game is high (Jennett, 1984). If a game result is predictable, people will be more worried than when the game starts soon. Therefore, football league committees should provide appropriate grounds to increase competitive balance (Koning, 2000). It is clear that sport leagues need a certain degree of competitive balance to survive and improve quality. Without competitive balance, the games are easily predicted and as a result they lose their attractiveness. Lack of competitive balance means that the number of spectators (those who go to the stadiums as well as those who watch the game on TV) is not maximized (Michie et al., 2004). Quirk and Fort (1992) asserted that one of the reasons why people love team sports is the excitement resulted from the uncertainty about the results of league competitions. To attract fans' interest, strengths and weaknesses of all league teams should be considered so that the uncertainty can exist for the results (Quirk et al., 1992). Competitive balance is important due to the fact that if other factors are considered to be similar, the uncertainty about the results will increase fans' interest and the need to watch games (either in stadiums or on TV). If a league is not balanced, it cannot earn revenues from the spectators and viewers. Therefore, it is important to increase and maintain competitive balance in order to maximize demand for a clubs, and the league's, product. This is an important business reason why sport leagues adopt disciplined regulations so that they can distribute revenues again and increase the balance. Competitive balance results in a balanced league as well. Imbalanced leagues face threats such as bankruptcy or threat to bankruptcy, weak clubs (retrograde), threats of competing leagues, a big gap in the intra-league (among league teams) and inter-league (among the teams of various leagues) revenues so that the teams which are selected for champions league and premier league can reach high revenues. Therefore, competitive balance is important for league certainty (Michie et al., 2004).

Many researches have been carried out on competitive balance as follows: Michie et al. (2004) investigated the leagues of England, Italy, Germany, France and Spain and observed a clear decline in the competitive balance of Italy A-series league since 1992 so that Italy league enjoyed the highest imbalance among the five European premier leagues at the end of 2004. Germany showed lower imbalance, but it generally enjoyed $n$ increasing approach (decreased competitive balance) in 10 recent years. France showed an increase in competitive balance since 1992, but it did not generally show a 
clear approach to competitive balance. In Spain, competitive balance enjoyed a rotating approach (a increase between 1956 and 1976 and an decrease afterwards). In England, competitive balance was stable in 40 years (1947-1987), but a sharp decline in competitive balance happened afterwards (Michie et al., 2004).

Goossens carried out a research on European leagues such as Germany, France, Portugal, Belgium, England ... and showed that Germany and France did not adopt a clear approach to the competitive balance of their leagues. Belgium and England showed a relative linear increase (i.e. a decrease in competitive balance) and Portugal was the only country which enjoyed a considerably negative linear decrease (i.e. an increase in competitive balance) (Goossens, 2006). Hann et al showed that England has decreased competitive balance. They presented weak evidences for such a decrease in Belgium and Holland and observed no clear approach to competitive balance in Germany, France, Italy and Spain (Hann et al., 2007).

Quirk and Fort investigated Holland football league and concluded that competitive balance dramatically decreased in the second half of 60 s and increased in the first half of 70 s and there was no clear approach afterwards. They also measured the long-term balance of five professional American leagues: American League (AL), National League (NL), National Basketball American (NBA), National Hockey League (NHL) and National Football League (NFL). They analyzed all five leagues and observed a dramatic imbalance (Quirk et al., 1992).

Mizak et al showed a dramatic decrease in competitive balance of Major League Baseball (MLB) since 1990 and America showed the highest decrease. As well, the lowest competitive balance was observed in Eastern Union of American League between 1998 and 2003 (Mizak et al., 2007). Eckard showed a decrease in competitive balance of AL and a increase in NL between 1975 and 1999 (Eckard, 2001). Zimbalist concluded that NBA was the most imbalanced league among the five American professional leagues. He also in his book (May the Best Team Win, Baseball Economies and Public Policy) noted that competitive balance gradually increased in MLB between 1903 and 1950 (Zimbalist, 2002).

In conclusion, competitive balance has been investigated in world leagues and in various years. The present study attempts to investigate the competitive balance in the last season of world football (20092010) in England, Germany, Italy, Spain, France and Iran.

\section{MATERIALS AND METHODOLOGY}

This study is descriptive and the data are secondary and were collected from valid documents and football league tables of Iran, England, Germany, Italy, France and Spain. This study aims to investigate competitive balance in football leagues of the above mentioned countries in 2009-2010 season. Two models were used in this study: The Five-Club Concentration Ratio (C5) and the C5 Index of Competitive Balance (C5ICB).

The above models were used in many researches (Dejonghe, 2006; Novotny, 2006; Szymanski et al., 2006; Feddersen, 2006; Tenreiro, 2006; Brunelli, 2006; Gouget et al., 2006; Michie et al., 2004, 2005). As these models were economic and mathematic indexes, it was not necessary to approve their validity and reliability.

In a totally balance league, C5ICB always equals 100 (Michie et al., 2004). An obtained C5ICB $>100$ shows a lower balance in that league. $\mathrm{C} 5$ in a totally balanced league changes by a change in the number of teams and as the leagues of this study consist of 18 and 20 teams: 
C5 ratio $=\frac{\text { total points won by the top five clubs }}{\text { total number of points won by all clubs }}$

C5 Index of Competitive Balance $=\left\{\frac{C 5}{\frac{5}{N}}\right\} * 100$

Where $\mathrm{N}$ is the number of teams in the league. If the obtained $\mathrm{C} 5$ is more than the above scores, that league enjoys lower balance (Michie et al., 2004).

\section{RESULTS}

Table 1 shows C5 and C5 Index of Competitive Balance (C5ICB) for the selected leagues. Table 2 shows scores gained by the teams of selected premier leagues.

Table 1. C5 and C5ICB in selected leagues.

\begin{tabular}{lcc} 
& C5ICB & C5 \\
\hline Spain & 149.60 & 0.374 \\
England & 148.00 & 0.370 \\
Italy & 140.00 & 0.350 \\
France & 138.00 & 0.345 \\
Germany & 135.37 & 0.375 \\
Iran & 129.60 & 0.359 \\
\hline
\end{tabular}


Table 2. Scores gained by the teams of selected premier leagues.

\begin{tabular}{|c|c|c|c|c|c|c|}
\hline & Spain & England & Italy & France & Germany & Iran \\
\hline 1 st & 99 & 86 & 82 & 78 & 70 & 67 \\
\hline $2^{\text {nd }}$ & 96 & 85 & 80 & 72 & 65 & 61 \\
\hline $3^{\text {rd }}$ & 71 & 75 & 70 & 71 & 61 & 59 \\
\hline $4^{\text {th }}$ & 63 & 70 & 67 & 70 & 59 & 53 \\
\hline $5^{\text {th }}$ & 62 & 67 & 65 & 69 & 57 & 52 \\
\hline $6^{\text {th }}$ & 58 & 64 & 59 & 64 & 55 & 48 \\
\hline $7^{\text {th }}$ & 56 & 63 & 55 & 58 & 52 & 47 \\
\hline $8^{\text {th }}$ & 54 & 61 & 52 & 55 & 50 & 46 \\
\hline $9^{\text {th }}$ & 47 & 50 & 51 & 53 & 47 & 42 \\
\hline $10^{\text {th }}$ & 47 & 50 & 50 & 52 & 46 & 42 \\
\hline $11^{\text {th }}$ & 44 & 47 & 47 & 48 & 42 & 41 \\
\hline $12^{\text {th }}$ & 43 & 46 & 46 & 48 & 39 & 41 \\
\hline $13^{\text {th }}$ & 42 & 44 & 45 & 47 & 38 & 39 \\
\hline $14^{\text {th }}$ & 41 & 39 & 44 & 47 & 35 & 38 \\
\hline $15^{\text {th }}$ & 40 & 38 & 44 & 44 & 33 & 38 \\
\hline $16^{\text {th }}$ & 39 & 36 & 44 & 41 & 31 & 37 \\
\hline $17^{\text {th }}$ & 37 & 35 & 42 & 40 & 28 & 32 \\
\hline $18^{\text {th }}$ & 36 & 30 & 35 & 32 & 24 & 30 \\
\hline $19^{\text {th }}$ & 36 & 30 & 31 & 31 & & \\
\hline 20th & 34 & 19 & 29 & 23 & & \\
\hline
\end{tabular}

Figure 1 show that C5ICB ranks the leagues (ranging from highest balance to the lowest balance) as follows: Iran Pro League, Germany Bundesliga, French 1st League, Serie A, Italy, Premier League, England and Primera Liga, Spain. 


\section{C5ICB}

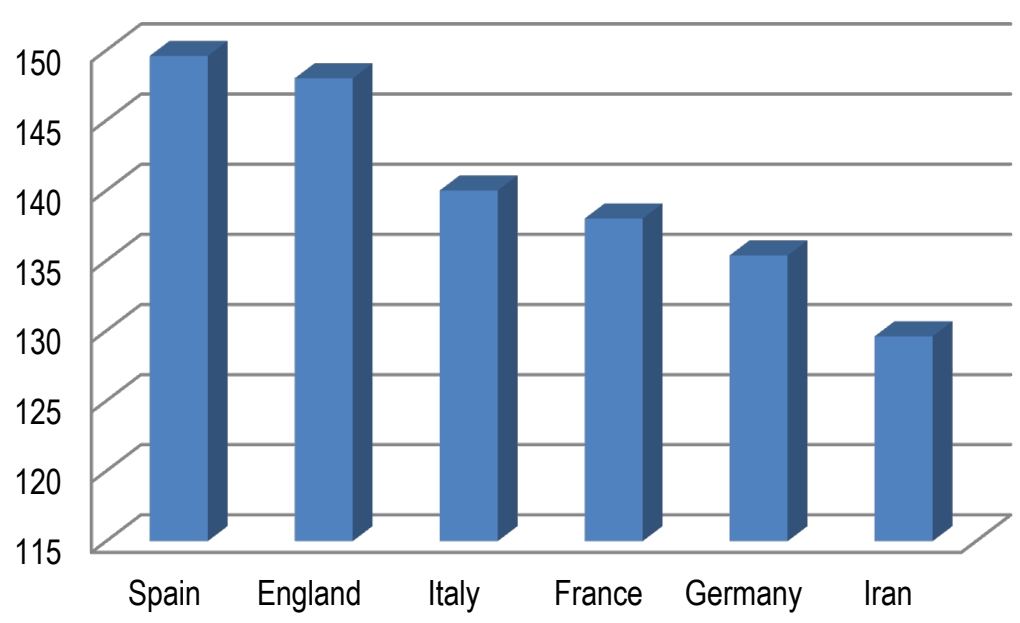

Figure 1. C5ICB in selected countries.

Figure 2 shows that $\mathrm{C} 5$ ranks the leagues (ranging from highest balance to the lowest balance) as follows: French 1st League, Serie A, Italy, Iran Pro League, Premier League, England, Primera Liga, Spain and Germany Bundesliga.

\section{C5}

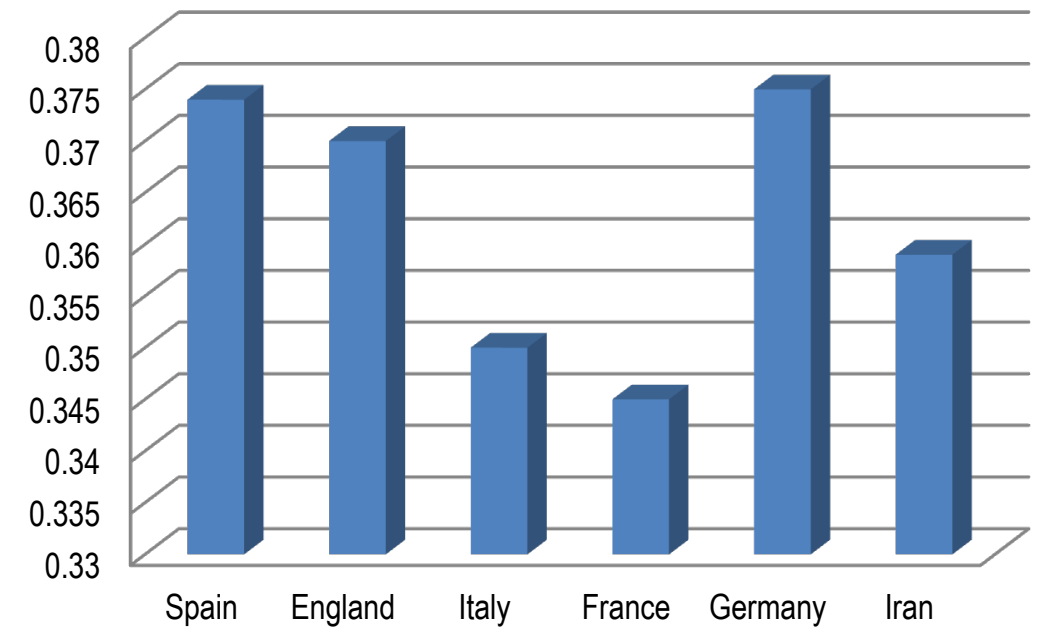

Figure 2. C5 in selected countries. 


\section{DISCUSSION AND CONCLUSIONS}

Figures 1 and 2 showed C5 and C5ICB findings for Iran, Germany, France, Italy, England and Spain leagues. $\mathrm{C} 5$ ranks these leagues (ranging from the highest balance to the lowest balance) as French 1 st league, Serie A, Italy, Iran Pro League, premier league, England, Primera Liga, Spain and Germany Bundesliga. But as Iran Pro League and Germany Bundesliga consist of 18 teams and other leagues consist of 20 teams and as $\mathrm{C} 5$ is not sensitive to a change in the number of teams, the results of this index may be uncertain in some cases. As a result, C5ICB is considered as the main index of this study as it is sensitive to a change in the number of teams. C5ICBs of Spain and England leagues are higher than other leagues which show a lack of competitive balance in these two leagues. If we look at the final table of 2009-2010 season in Primera Liga, Spain, we can observe the clear difference between the scores of Real Madrid and Barcelona and those of other teams. One of the main reasons for this difference is that these two teams annually go to Champions League; as a result, they reach huge financial resources (such as TV broadcasting) and they can attract famous players. Another reason for this difference dates back to the history of Real Madrid and Barcelona teams. Real Madrid has always been supported by Spain governors, especially General Franco. On the other hand, Barcelona has always been supported by people (especially autonomous Basque city).

In England, Chelsea and Manchester United teams enjoy almost similar conditions. Chelsea team owes its position to its managers' financial support. They could invite famous players to this team by paying astounding expenses while the expenses of a team such as Portsmouth during a season may be lower than the expenses of contracting three players to Chelsea team. It is also possible that Manchester City club like Chelsea and Manchester clubs can claim the league using its managers' financial support in near future.

After these two leagues, Serie A, Italy is the third imbalanced league. The final table of this league shows that Inter Milan and AS Roma teams in Serie A enjoy conditions similar to Chelsea and Manchester teams in the premier league and they claimed to win before the end of the league. One of the possible reasons why competitive balance decreased in Serie A is Italian sport authorities' viewpoints on football which has always been political; A.C. Milan, Juventus, Inter Milan... teams are comprised of politicians and famous Italian families. They financially support these clubs and as a result they can attract best players in the world. For example, Inter Milan team won Serie A and European Champions League while there were no Italian players in this team.

French 1 st League is the fourth imbalanced league and it can be mentioned that it enjoys an acceptable balance. There is a 3-point difference between the second and fifth teams. It means that it was possible that the fifth team could occupy the second place in the league if it had one more winning. One of the main reasons for such a situation is similar financial resources as well as government's viewpoint on football. If we look at the players of this league, we can see very few elite players and as far as Real Madrid, Barcelona, Manchester, Chelsea... clubs exist, French clubs cannot financially attract elite players. Most players in this league are native or from African countries which were colonies under France's control.

Germany Bundesliga is the second balanced league. The table of this league shows a 2- to 3-point difference between each team and its upper team while there is a 25 -point difference between the second and third team in Primera Liga, Spain and a 10-point difference in England and Italy leagues. German clubs like France clubs depend on their native players and basic teams. 
Iran Pro League is most balanced and there is a 2-point difference between the ninth and twelfth teams and a 5-point difference between the ninth and sixteenth teams. Since the last week of the league, it was not clear whether the four teams would remain in the premier league or decline to 1 st league. In this league, Sepahan Isfahan was the only team that occupied the first place for 20 weeks and had higher quality. A team can be successful due to the following reasons:

1. Extreme financial support by club sponsor

2. Stability of club management

3. Experienced technical staff

4. Qualified players

5. Spectators and fans' support

It can be mentioned that Sepahan is the only Iranian team which enjoys all the above conditions. Iran football is not a traditional and bipolar anymore so that six teams could have won the premier league within 9 years and no teams could win the premier league more than twice. As two teams from Isfahan city, one team from Kerman city and one team from Tehran city went to Asia Champions League this season, it can be said that Iran football is not traditional and focused on Tehran city anymore and it is rapidly growing in other regions such as Isfahan, Kerman, Tabriz... Finally, it is necessary to mention that as the mentioned leagues have recently finished and no research has been carried out accordingly, it is not possible to compare the results of this study with other researches.

\section{REFERENCES}

1. ALBERT J, KONING RH. Statistical thinking in sports. New York: Chapman \& Hall/CRC; 2008. [Abstract] [Back to text]

2. BRUNELLI M. The impact of UEFA Champions League upon domestic championships: the Italian serie A. Nyon: UEFA/IASE Seminar; May 2nd, 2006. [Back to text]

3. DEJONGHE T. The evolution of Belgian football over the last decades. Nyon: UEFA/IASE Seminar; May 2nd, 2006. [Full Text] [Back to text]

4. ECKARD E. Free Agency, Competitive Balance, and Diminishing Returns to Pennant Contention. Econ Inq. 2001; 39:430-443. [Full Text] [Back to text]

5. FEDDERSEN A. Economic consequences of the UEFA champions league for national championships; the case of Germany. Nyon: UEFA/IASE Seminar; May 2nd, 2006. [Abstract] [Back to text]

6. GOOSSENS K. Competitive Balance In European Football: Comparison By Adapting Measures: National Measures Of Seasonal Imbalance And Top 3. Journal of Diritto ed Economia dello Sport. 2006; 2(2):77-122. [Full Text] [Back to text]

7. GOUGET JJ, PRIMAULT D. The economic impact of the UEFA Champions League on the French football championship. Nyon: UEFA/IASE Seminar; May 2nd, 2006. [Back to text]

8. HAAN MA, KONING RH, VANWITTELOOSTUIJN A. The effects of institutional change in European soccer. Mimeo: University of Groningen; 2007. [Back to text]

9. HALICIOGLU F. The impacts of football point systems on the competitive balance: evidence from some European football leagues. Rivista di Diritto Economia Dello Sport. 2006; 2(2):6776. [Full Text] [Back to text]

10. JENNETT N. Attendances, Uncertainty of Outcome and Policy in Scottish Football League. Scot J Polit Econ. 1984; 33:176-198. doi:10.1111/j.1467-9485.1984.tb00472.x [Back to text]

11. KONING RH. Balance in competition in Dutch soccer. The Statistician. 2000; 49(2):419-431. [Full Text] [Back to text]

12. MICHIE J, OUGHTON C. Competitive Balance in Football: An Update. London: The Sports Nexus; 2005. [Back to text] 
13. MICHIE J, OUGHTON C. Competitive Balance in Football: Trends and Effects. London: The Sports Nexus; 2004. [Back to text]

14. MIZAK D, NERAL J, STAIR A. The adjusted churn: an index of competitive balance for sports leagues based on changes in team standings over time. Economics Bulletin. 2007; 26(3):1-7. [Full Text] [Back to text]

15. NOVOTNY J. Economic trends in Czech football teams and UEFA. Nyon: UEFA/IASE Seminar; May 2nd, 2006. [Back to text]

16. QUIRK J, FORT R. Pay Dirt: The Business of Professional Team Sports. Princeton: Princeton University Press; 1992. [Abstract] [Back to text]

17. SZYMANSKI S, LEACH S. Report on the English top division 1980-2005. Nyon: UEFAIIASE Seminar; May 2nd, 2006. [Back to text]

18. SZYMANSKI S. Income inequality, competitive balance and the attractiveness of team sports: some evidence and a natural experiment from English soccer. Econ J. 2001; 111:F69-F84. [Full Text] [Back to text]

19. SZYMANSKI S. The Economic Design of Sporting Contests. J Econ Lit. 2003; 41:1137-1187. [Full Text] [Back to text]

20. TENREIRO F. Can European football David's equal their Goliath's? The Portuguese case assessesment. Nyon: UEFA/IASE Seminar; May 2nd, 2006 [Back to text]

21. ZIMBALIST AS. Competitive Balance in Sports Leagues: An Introduction. Journal of Sports Economics. 2002; 3(2):111-121. doi:10.1177/152700250200300201 [Back to text] 